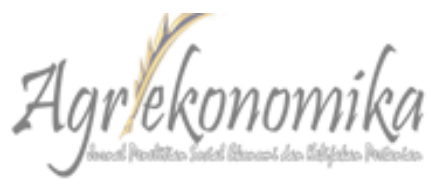

Jurnal Sosial Ekonomi dan Kebijakan Pertanian

http://journal.trunojoyo.ac.id/agriekonomika

Agriekonomika Volume 5, Nomor 2, 2016

\title{
INTEGRATED DISEASE MANAGEMENT FOR CHILI FARMING IN BREBES AND MAGELANG - CENTRAL JAVA: SOCIAL ECONOMIC IMPACTS
}

\author{
Joko Mariyono \\ Program Studi Magister Manajemen, Universitas Pancasakti-Tegal \\ mrjoko28@gmail.com
}

\begin{abstract}
Received : 29 August 2016; Accepted: 09 October 2016; Published: 31 October 2016 DOI: http://dx.doi.org/10.21107/agriekonomika.v5i2.1686
\end{abstract}

\begin{abstract}
This study aims to analyze the impact of an integrated disease management (IDM) on chilli. Chili disease control technologies that include crop barrier with corn and Crotalaria, and compost tea have been introduced to farmers in Magelang and Brebes. A qualitative approach was used to assess and estimate the socio-economic impact of agricultural research. The study was conducted in 2011. The results showed that the net economic benefits generated was relatively low. There were only a few farmers who have adopted the technology on chili. Furthermore, the survey also illustrates that three years after its introduction in 2007 the technology status at farm level was just at consciousness phase. Learning of this fact, a comprehensive evaluation of the technology on chili should be done immediately. Research institutions which have developed the technology should encourage bottom-up initiatives and build a shared commitment to complete the implementation of a clear strategic plan. The adoption of the strategic plan should include the integration of research activities with promotional activities for example by revitalizing participatory approaches to awareness of farmers.
\end{abstract}

Keywords: Chili production, integrated disease management, adoption, socio-economic

\section{INTRODUCTION}

Farming of vegetables, including chili, plays an important role in agriculture economy. This provide more income and employment than cereal and staple crops sectors (Ali 2006; Johnson et al., 2009; Weinberger and Genova II, 2005; Weinberger and Lumpkin, 2007;) as well as healty foods because of high vitamins and essential micro-nutrients (Latifah et al., 2014). As a commercial crop, has been cultivated in developing countries over couple past decades. This commodity has high economic value, because it is needed for daily dietary as well as for raw material of food and pharmaceutical industries.

\footnotetext{
Corresponding author:

Address : Jalan Halmahera km-1, Tegal, Jawa Tengah, Indonesia

Email : mrjoko28@gmail.com

Phone : +62 81328175833
}

Chili farming, in particular, has been able to revitalize rural economy thorugh increases in farmers' income, agricultural factor market and employment (Bhattarai and Mariyono, 2016; Mariyono and Bhattarai, 2011).

In Indonesia, chili-planted area is the highest among other vegetables, despite the production of cabbage is the highest. White et al. (2007) reported that chili production uses $20 \%$ of the vegetable land but only produces $12 \%$ of the total vegetable output due to low average yields. Whereas, both cabbage and potato use only $6.3 \%$ and $6.8 \%$ respectively of the vegetable land and have much higher p-ISSN 2301-9948 | e-ISSN 2407-6260 
yields resulting in large volumes of produce. For chili, per hectare production averages for the Indonesia are low by regional and international standards. In spite of low productivity, farmers are still motivated to grow chili (Mariyono and Sumarno, 2015). The need of chili is increasing fast in line with the increase of income and/or the number of population as seen on the demand trend that tended to increase from $2.45 \mathrm{~kg} /$ capita in 1988 to $2.88 \mathrm{~kg} /$ capita in 1990 , and $3.16 \mathrm{~kg} / \mathrm{capita}$ in 1992 (Bank of Indonesia, 2007).

Because chili can provide significant contribution to Indonesian economy, if farmers rapidly adopt the modern technology, it is expected to contribute more important roles in the economy. Nevertheless, adoption of improved technology faces many socio-economic and sociological factors (Kuntariningsih and Mariyono, 2014; 2013a). Consequently, the adoption of newly introduced technology has met with only partial success. Farmers' training is one of the best ways to introduce new agricultural technologies (Kuntariningsih and Mariyono, 2013b). When farmers adopt such technology, they will gain benefits (Mariyono, 2013). One of examples is adoption improved varieties (Mariyono, 2016), which is suitable in off season that generate high profit in shallot farming (Purba, 2014). Vegetable farming in off season can gain higher profit because of better prices (Negoro and Mariyono, 2014). The role of private sector has a potential to increase the adoption rate of agricultural technology through a program called corporate social responsibility (Kuntariningsih, 2014). Thus, while talking with agricultural expert and chili farming in many sites, they frequently analyzed some of the constraints to the rapid adoption of chili such as lack of credit, limited access to technological and market information, inadequate holding of farmsize, insufficient human capitals, chaotic supply of complementary inputs, and inappropriate transportation infrastructure. Indonesian Vegetable Research Institute (IVegRI) has been conducting research since the 1980s chili. Chili has positioned as one of the priority commodities research since last 10 years. Development of chili is basically directed to fulfil domestic consumption, to meet the needs of industrial raw materials, to substitute import, and to fill in the export market opportunities. This needs to be taken in order to achieve the ideal conditions of future agribusiness profile that has the characteristics: (i) as the largest producer and exporter in Southeast Asia, (ii) as a source of income is high for all participants along the supply chain, (iii) high levels of productivity and (d) higher product competitiveness (Badan Litbang Pertanian, 2007).

For more than 25 years, Idonesian Vegetable Research Intitute (IVegRI) has designed disease control technology/ IDM to support agribusiness development strategy for chili. Dealing with pests and dieases if one focuses of Indonesian plant protecting strategy (Mariyono, 2015). Some disease control technologies that have been released are: border systems, net systems, natural pesticides. Meanwhile, disease control technology/IDM for cultivation of chilli has been produced IVegRI is basically designed with due regard to the principles of sustainability. Judging from the output side, technology, disease control/IDM chili produced by IVegRI actually have been quite complete. However, as a public research institute that most sources of funding comes from national budget, the accountability of research cannot be fulfilled if the activities stop at the achievement of output perse. In the meantime, questions regarding "the extent to which technology-disease control/IDM chili generated by IVegRI has been adopted by farmers" and "the extent to which the adoption of IDM technology IVegRI has contributed to improvement of welfare of chili farmers", is the essential questions that have almost never been answered satisfactorily. The achievement of outcomes and impact is not fully understood as necessary conditions and the existence of performance measures 
research institutions. In line with the description above, this study aims to analyze the impact of IDM chilli and analyze the adoption.

\section{METHODOLOGY}

\section{Data Systems for Impact Assessment}

Impact assessment is an activity that is very intensive data collection. Collecting accurate data is a component of the most time-consuming and costly than the implementation of impact assessment. The research program is usually the ideal balance the needs of data (and likely cost), with a practical, and requires the collection from various sources. Institutionalization of the data system also provides assurance that the information generated from research activities can be available in a systematic and timely manner, so that it can be used for future needs.

\section{Studi Sites and Analitical Approach}

After going through the stages of planning and preparation (desk study, team discussions, preparation of questionnaire and survey design) study was conducted in August-September 2010. Research activities conducted in Central Java as the center of chili-producing regions (lowland and medium). This study is a survey with respondents are chili farmers, was directed to explore and estimate the potential for disease control manegemen technology/IDM chili. The selection of respondents is purposively determined, based on the methods to be used (field survey) in accordance with the principle of representativeness.
This study uses a quantitative noncorelational approach, where variables analysed here are presented in descriptive fashion (Sugiyono, 2016). This approach is used because the selected variables were explored and analysed based on the current issues, that is, adoption of technology in agriculture is not as always smooth as expected..Analysis of the impact of technology adoption IDM involves some parameters (Alwang and Siegel, 2003; Alene, et al., 2005) as follows: (a) the efficiency (increased productivity, reduced cost of production/unit), (b) adoption rate ceiling (percentage farmers who adopt the maximum IDM technoogy, (c) constraints and determinants of technology adoption IDM, (d) The production of commodities and inputs used. The analysis tools are: (1) descriptive statistics and content analysis (for qualitative and quantitative data), (2) cost-benefit analysis and partial budget analysis (Alston et al., 1995).

The study was conducted in six locations in Magelang and Brebes, Central Java. In Magelang the locations include Sawangan, Kaliangkrik, Muntilan, Salam, Secang; while in Brebes the location is Kersana. These six locations correspond to areas targeted by a project for field farmer training and chili IDM diffusion. This study refers to 14 farmers as "farmer cooperators" or innovators and early adopters of farm technologies (Rogers, 1995). This is based on the belief that if farmer cooperators are convinced, it is then more likely that they would persuade other farmers to try the technologies (Feder and Savastano, 2006).

Table 1

Characteristics of the Study Locations for the Chili IDM 2009

\begin{tabular}{|c|c|c|c|c|c|}
\hline Locations & Altitude (m) & $\begin{array}{l}\text { Cultivated } \\
\text { area (ha) }\end{array}$ & $\begin{array}{l}\text { Chili area } \\
\text { (ha) }\end{array}$ & $\begin{array}{l}\text { Main } \\
\text { crop }\end{array}$ & Cropping pattern \\
\hline Sawangan, Magelang & $410-450$ & 1,653 & 151 & Rice & Chili-rice, Chili-rice-rice \\
\hline Kaliangkrik, Magelang & $600-670$ & 1,542 & 247 & Rice & Tomato/yard long bean - Chili-rice \\
\hline Muntilan, Magelang & 400 & 1,848 & 92 & Rice & Chili-rice-vegetable crops-rice \\
\hline Salam, Magelang & 410 & 1,903 & 102 & Rice & $\begin{array}{l}\text { Rice- maize-Chili-rice } \\
\text { Maize-chili-rice-rice }\end{array}$ \\
\hline Secang, Magelang & 450 & 2,798 & 21 & Rice & Chili-rice-maize \\
\hline Kersana, Brebes & 110 & na & & $\begin{array}{l}\text { Shallot/ } \\
\text { chili }\end{array}$ & $\begin{array}{l}\text { Rice-Shalot-Shalot, Rice-Shalot- } \\
\text { Chili. }\end{array}$ \\
\hline
\end{tabular}




\section{Adoption Studies}

Adoption studies were carried out to monitor the levels and phases of adoption and impact of tested technologies on productivity at farm level on the promotion stage of technology. This study measures the extent to which the application of technological progress, the performance of technology (productivity changes, advantages and disadvantages), farm management changes resulting from the use of new technologies, and characteristics of the diffusion process. Important information obtained from this study are: (a) the degree and speed of adoption and the reasons for non-adoption, (b) farmers' perceptions regarding the desired characteristics of the technology options available, (c) productivity at farm level and improvement/acquisition revenue as a result of biotic and abiotic constraints (d) the impact on household welfare of farmers, for example relating to the distribution of income within households, nutrition and health, and (e) constraints of infrastructure, institutions and policies that hinder the adoption of technology (Morris et al. 1999; Sain and Martinez, 1999; Knepper, 2002.).
Perceptions of farmers regarding an important constraint, the desired characteristics farming will be very useful for (a) help identify the essential constraints and opportunity studies, (b) provide an empirical basis for estimating the upper limit of the rate of adoption, and (c) give assurance that the option-research options that are designed based on user needs will have a high adoption rate. Adoption studies are usually conducted as a case study based on the views of researchers/scientists on considerations of interest and potential of various types of technology, research costs, and availability of funding (Chamber et al., 1989).

\section{RESULT AND DISCUSSION \\ Cost and Benefit Analysis of IDM Technology for Chili}

Table 2, shows material cost and other costs related to implementation of technology in Sawangan, Magelang. Total material cost ranges from $46 \%$ (Rp570,000) to $49 \%$ (Rp 56,000). Other cost ranges from $51 \%$ (Rp580,000) to 54\% (Rp670,000). IDM border corn can increase cost (material cost and other cost) compare to Control 15\% (Rp160,000) and 6\% (Rp60,000) for IDM clotalaria border.

Table 2

Costs and Returns of Farmer Plot Chili IDM Production, Magelang, Dry Season 2010

\begin{tabular}{|c|c|c|c|c|c|c|c|c|c|}
\hline \multirow[t]{2}{*}{ Particulars } & \multicolumn{3}{|c|}{ Corn barier } & \multicolumn{2}{|l|}{ Control } & \multicolumn{4}{|c|}{ Barier Crotalaria } \\
\hline & P1 & $\mathrm{P} 2$ & Total & P1 & $\mathrm{P} 2$ & Total & P1 & $\mathrm{P} 2$ & Total \\
\hline Total Expenses ((Rp) & & & 1540000 & & & 1380000 & & & 1440000 \\
\hline - Materials (Rp)/\% & 570000 & 37 & & 585000 & 42 & & 560000 & 39 & \\
\hline - Other cost (Rp)/\% & 670000 & 44 & & 495000 & 36 & & 580000 & 40 & \\
\hline Production (Kg) & & & 235 & & & 167 & & & 349 \\
\hline $\begin{array}{l}\text { Total harvesting (times) } \\
\text { Healthy plants }(\%) / / \\
\text { Helicoverpa }\end{array}$ & & & 17 & & & 17 & & & 17 \\
\hline $\begin{array}{l}\text { Increase produc vs. } \\
\text { control }(\%)\end{array}$ & & & $\begin{array}{l}92 \\
29\end{array}$ & & & 93 & & & $\begin{array}{l}95 \\
52\end{array}$ \\
\hline Average price(Rp) & & & 8824 & & & 8824 & & & 8824 \\
\hline Total Income (Rp) & & & 1796838 & & & & & & 3226353 \\
\hline Cost/plant (Rp) & & & 3850 & & & 3450 & & & 3600 \\
\hline Revenue & & & 256838 & & & 42103 & & & 1786353 \\
\hline $\mathrm{R} / \mathrm{C}$ ratio & & & 0.17 & & & 0.03 & & & 1.24 \\
\hline
\end{tabular}


Table 3

Cost and Returns (per 1200 plants $/ 1000 \mathrm{~m}^{2}$ ) of Farmes Plot Chili IDM Production, Magelang, Dry Season Nov 2009

\begin{tabular}{|c|c|c|c|c|c|}
\hline \multirow[b]{2}{*}{ Particulars } & \multicolumn{2}{|c|}{ Com Barier } & \multirow{3}{*}{$\begin{array}{c}\text { Control } \\
\text { Sawangan } \\
\text { Nov } 2009 \\
\end{array}$} & \multicolumn{2}{|c|}{ Barier Crotalaria } \\
\hline & $\begin{array}{l}\text { Salam Aug } \\
2009\end{array}$ & & & Sawangan & Jov 2009 \\
\hline Total Expenses (Rp) & & 3265000 & & & 4749000 \\
\hline - Materials (Rp)/\% & $1365000 \quad 42$ & & & $1994000 \quad 42$ & \\
\hline - Other cost (Rp)/\% & $1900000 \quad 58$ & & & $2755000 \quad 55$ & \\
\hline Production (Kg) & & 395 & 334 & & 360 \\
\hline $\begin{array}{l}\text { Total harvesting } \\
\text { (times) }\end{array}$ & & 19 & 17 & & 17 \\
\hline $\begin{array}{l}\text { Healthy plants (\%)/ } \\
\text { antrh }\end{array}$ & & 62 & 93 & & 65 \\
\hline $\begin{array}{l}\text { Increase prod VS } \\
\text { control (\%) }\end{array}$ & & 15 & & & 5 \\
\hline Average prevailing & & 2721 & & & 3958 \\
\hline Total Income (Rp) & & 1073369 & & & 1385125 \\
\hline Cost/plant (Rp) & & 2721 & 0 & & 3958 \\
\hline $\begin{array}{l}\text { Revenue } \\
\mathrm{R} / \mathrm{C} \text { ratio }\end{array}$ & & $\begin{array}{r}-2191631 \\
-067 \\
\end{array}$ & 0 & & $\begin{array}{r}-3363875 \\
-0.71 \\
\end{array}$ \\
\hline
\end{tabular}

Productivity: In terms of yields from Chili IDM pilot plot productivity is higher than control. Compare to control, using IDM technology can increase up to $29 \%$, and $52 \%$. R/C ratio: Both of technology border corn or clotalaria has give positive $\mathrm{RC} /$ ratio bteween 0.17 and 1.24 (Table 2).

Table 3 shows total cost (material cost and other costs) in all sample of Magelang. Total expenses for material cost in IDM border corn 42\% (Rp1,365,000) and other cost $58 \%$ (Rp1,900,000). IDM border clotalaria for material cost $42 \%(\mathrm{Rp} 1,994,000)$ and other cost $58 \%$ $(\mathrm{Rp} 2,775,000)$. In terms of productivity, IDM technology provided higher yield than control, by $26 \%$, and $17 \%$. Both of technology border corn or clotalaria has give negative RC/ratio between -0.67 and -0.71 .

Table 4, shows total cost (material cost and other cost) related to implementation of technology in Brebes. Material cost ranges from 35\% $(R p 1,365,000)$ to $65 \%(R p 2,543,300)$. In term of productivity, yield in IDM technology was low, that is $166 \mathrm{~kg}$ or about $1,840 \mathrm{~kg}$ per hectare. $\mathrm{R} / \mathrm{C}$ ratio gives negative $\mathrm{RC} /$ ratio of -0.11 . The size and distribution of economic benefits were estimated R/C ratio in pilot plot has indicate economic surplus. But, when the technology was implemented in farmer plot, it has negative due to low selling price. Condition in Brebes was diferent because at the time the plant was attacked by fruit borer, so production became low.

\section{Adoption Status of IDM}

In Central Java, Magelang and Brebes are chili production area frequently used as sites for testing IDM technology, since both areas are the two largest chili producers in Central Java. In 2007 field trials of IDM technology was conducted to test crop-border system, and compost tea, which were considered as component of IDM technology specifically addressing disease problem in chili farming. Magelang and Brebes were chosen as the location of impact studies of IDM technology. The survey was conducted using individual interviews with farmers. A set of structured questionnaires was used to guide interview. Attachment 1-2 below are farmers' answers to raised questions. 
Table 4

Costs and returns of plot chili IDM, Brebes, 2010

\begin{tabular}{|c|c|c|}
\hline \multirow[t]{2}{*}{ Particulars } & \multicolumn{2}{|c|}{ Compost tea } \\
\hline & Kresna/Brebes Jan 2010 & Total \\
\hline Total Expenses (Rp) & & $3,908,300$ \\
\hline Material input (Rp)/\% & $1,365,000$ & \\
\hline Other cost $(\mathrm{Rp}) / \%$ & $2,543,300$ & \\
\hline production (Kg) & & 166 \\
\hline total harvesting (times) & & 8 \\
\hline Healthy plants (\%)/Helicoverpa & & 12 \\
\hline Average pervailing price (Rp) & & 3,000 \\
\hline Chii Income (Rp) & & 496,800 \\
\hline Shallot income (Rp) & & $3,000,000$ \\
\hline Total Income (Rp) & & $3,496,800$ \\
\hline Cost/plant (Rp) & & 3,257 \\
\hline Revenue & & $-411,500$ \\
\hline $\mathrm{R} / \mathrm{C}$ ratio & & -0.11 \\
\hline
\end{tabular}

Source: Analysis of Primary Data, 2011

Based on that result, next question need to be answer is why until now IDM chili has not been adopted yet by the farmers even though the technology is already accepted. Why a lot of good things in the technology like (high productivity, low cost and more enviromentally friendly etc) and non-technical aspects (farmer preference). IDM technology technology still does not enough provide interest to others farmers. Some study give pictures of new technology adoption that has influenced by various factors like: (a) characteristic of the technology it self, (b) farmer characteristic, and (c) characteristics of farm environment. So explanation about the IDM technology has not been adapted yet. Using qualitative methods it can be check using all that factors (Anderson, 2005).

Important characteristics in a new technology can be supported or not for adoption are: (a) complexities, (b) profitability, (c) risk, (d) compatibility, and (e) diversibility. So IDM tecnology for chili is not fulll different from conventional one in how to grow chili. In these cases, plus border plants which grow 30 days before plant main crop in the only difference.

\section{CONCLUSION}

The results of this study indicate that, at present, there is little demand for IDM technology for chili, at least in established chili-growing areas. Most farmers who obtained IDM tecnology were interested in comparing its performance with convensional technology, that is growing chili without crop border. However, we could find little evidence that experienced farmers with chili IDM were willing to do again the technology by growing chili more than one using IDM technology. This study used cost benefit analytical framework to evaluate the walfare impact of developing, releasing, and adopting IDM chili during 2007-2010. The size and distribution of economic benefit estimated using R/C ratio in pilot plot has indicate economic surplus. On the other hand, when technology implemented in farmer plot has negative due to very low selling price at the time. If the price was considered normal, there was still positive margin. This study has concentrated on the monetary benefits and costs of IDM chili and did not address issues such as as environmental externlities. Based on this evidence, thorough evaluation of IDM technology for chili should be done immediately. IVegRI and AVRDC have to support bottom-up initiatives and build a mutual commitment to completing the implementation of a clear 
strategic plan. Adoption of a strategic plan should include the integration of research activities with promotional activities such as through the revitalization of farmers' awareness participatory approach.

\section{ACKNOWLEDGEMENTS}

The authors thank the farmers who kindly gave their time to provide detailed information for the analysis. High appreciation for the valuable technical inputs provided by Paul Gniffke of AVRDC; Anna Dibiyantoro, and Rachman Suherman of IVegRI. Thanks the Australian Centre for International Agricultural Research (ACIAR) for the grant support to AVRDC - The World Vegetable Centre and its consortium of partners to implement the chili project in Central Java, Indonesia (ACIAR Project HORT/2004/048).

\section{REFERENCES}

Alene, A.D., Manyong, V.M. Gockowski, J.. Coulibaly, $\mathrm{O}$ and Abele, S.. 2005. A framework for conceptualizing impact assessment and promoting impact culture in agricultural research. International Institute of Tropical Agriculture (IITA), Ibadan, Nigeria.

Alston, J.M., Norton, G.W. and Pardey, P.G.. 1995. Science Under Scarcity. Principles and Practice for Agricultural Research Evaluation and Priority Setting. Cornell University Press and ISNAR. Ithaca.

Alwang, J. and Siegel, P.B.. 2003. Measuring the impacts of agricultural research on poverty reduction. Agricultural Economics 29:1-14.

Anderson, J.B., Desmond, A. and Green, J.R. 2005. Determinants of farmer adoption of organic production methods in the fresh-market produce sector in California: A logistic regression analysis. Western Agricultural Economics Association Annual Meeting.
Badan Litbang Pertanian, 2007. Prospek dan Arah Pengembangan Agribisnis Komoditas Bawang Merah. Badan Penelitian dan Pengembangan Pertanian. Jakarta.

Bank of Indonesia 2007. Lending Model Information System for SmallScale Enterprises: Medicinal plant cultivation. The Bank of Indonesia, Jakarta.

Bhattarai, M. and Mariyono, J. 2016. The economic aspects of chilli production in Central Java. Economic Journal of Emerging Markets 8(2): 85-97.

Feder, G. and Savastano, N. 2006. The role of opinion leaders in the diffusion of new knowledge: the casa of integrated pest management. World Development 34:1287-1300.

Johnson G., Weinberger K. and Wu, M.E. 2008. The Vegetable Industry in Tropical Asia: An overview of production and trade with a focus on Thailand, Indonesia, the Philippines, Vietnam, and India. Exploration series: No. 1, AVRDC - The World Vegetable Center, Shanhua, Taiwan.

Knepper, E.T. 2002. Factors affecting the use of fertilizer by small- and mediumsized farming households in Zambia, 1997 to 2000. A thesis submitted to the Department of Agriculture and Natural Resources, Michigan State University.

Kuntariningsih, A. 2014. Model dan kajian sosiologis program corporate social responsibility pada perusahaan benih PT East West Seed Indonesia. SEPA Jurnal Sosial Ekonomi Pertanian dan Agribisnis 11(1): 8-20.

Kuntariningsih, A. and Mariyono, J. 2013a. Socio-economic factors affecting adoption of hybrid seeds and silvery plastic mulch. SEPA Jurnal Sosial 
Ekonomi Pertanian dan Agribisnis 9(2): 279-308.

Kuntariningsih, A. and Mariyono, J. 2013b. Dampak pelatihan petani terhadap kinerja usahatani kedelai di Jawa Timur. Sosiohumaniora 15(2): 139150.

Kuntariningsih, A. and Mariyono, J. 2014. Adopsi teknologi pertanian untuk pembangunan pedesaan: sebuah kajian sosiologis, Agriekonomika 3(2): 180-191.

Latifah, E., Andri, K.B., and Mariyono, J. 2014. Pengenalan model kebun sayur sekolah untuk peningkatan konsumsi sayuran bagi para siswa di Kediri - Jawa Timur. Agriekonomika 3(1): 34-44.

Mariyono, J. 2013. The benefits of training that introduced ecological technology. SEPA Jurnal Sosial Ekonomi Pertanian dan Agribisnis 9 (2): $309-316$

Mariyono, J. 2015. Green revolutionand wetland-linked technological change of rice agriculture in Indonesia, Management of Environmental Quality: An International Journal 26(5): 683-700.

Mariyono, J. 2016. Impacts seed technology improvement on economic aspects of chilli production in Central Java - Indonesia. Jurnal Ekonomi Pembangunan: Kajian Masalah Ekonomi dan Pembangunan 17(1): 1-14.

Mariyono, J. and Bhattarai, M. 2011. Revitalizing Indonesian rural economy through intensive farming of high value vegetables: a case of chili farming in Central Java. Indonesia's Regional Economy in the Globalization Era. IRSA Book Series on Regional Development No. 9,
2011: 71-89.

Mariyono, J. and Sumarno, S. 2015. Chilli production and adoption of chilli-based agribusiness in Indonesia. Journal of Agribusiness in Developing and Emerging Economies 5(1): 57-75.

Morris, M.L., Tripp, R. and Dankyi, A.A. 1999. Adoption and Impacts of Improved Maize Production Technology: A Case Study of the Ghana Grains Development Project. Economics Program Paper 99-01. D.F., CIMMYT, Mexico,

Negoro, A.A. and Mariyono, J. 2014. Peran sistem informasi dan teknologi luar musim dalam bisnis berbasis komoditas sayuran. Prosiding Seminar Nasional PERHORTI 2014, Malang 5-7 November 2014.

Purba, R. 2014. Produksi dan keuntungan usahatani empat varietas bawang merah di luar musim (off-season) di Kabupaten Serang, Banten. Agriekonomika 3(1): 55-64.

Rogers, E.M. 1995. Diffusion of Innovations. ( $5^{\text {th }}$ edition). Glencoe: Free Press, USA.

Sain, G., and Martinez, J. 1999. Adoption and Use of Improved Maize by Small-Scale Farmers in Southeast Guatemala. CIMMYT Economics Paper 99-104: CIMMYT. Mexico D.F

Statistical Bureau, 2010. Magelang Dalam Angka. Biro Statistik Magelang.

Sugiyono, 2016. Metode Penelitian Kuantitatif, Kualitatif, dan R\&D. Alfabeta. Bandung.

Weinberger, K., Genova II, CA. (2005). Vegetable Production in Bangladesh: Commercialization and Rural Livelihoods. Technical Bulletin No. 33. AVRDC publication number 05- 
621. AVRDC - The World Vegetable Center, Shanhua, Taiwan. 36 pp.

Weinberger, K., Lumpkin, T,A. 2007. Diversification into horticulture and poverty reduction: a research agenda. World Development 35(8): 1464-1480

White, B., Morey, P., Natawidjaja, R., and Morgan, W., 2007. Vegetable value chains in Eastern Indonesia-a focus on chilli. SADI-ACIAR Research Report, Indonesia Australia Partnership. 
Attachment 1. Knowledge and farmer reaction to the presence of IDM for chili regarding to history of IDM

\begin{tabular}{lc}
\hline Questions & Answers \\
& $\%(n=14)$ \\
\hline Do you know about IDM for chili? & 100.0 \\
$\bullet \quad$ I hear & 0.0
\end{tabular}

Where do sources of that technology come from?

- Other farmer $\quad 7.1$

- Other farmer in the same group 0.0

- Agriculture service (extension or other agriculture service/ PHP) 64.3

- In cooperative project $\quad 21.4$

- $\quad$ other.................

What is your reaction after you know IDM for chili?

- Not sure $\quad 21.4$

- $\quad$ Directly interesting 78.6

What do you do after you know technology IDM for chili?

- Directly try in the field with other farmer $\quad 35.7$

- $\quad$ Try own self in the next season $\quad 64.3$

- In general 0

Source: Analysis of primary data, 2011

Attachment 2. Knowledge and farmer reaction to the presence of IDM for chili regarding to opportunity used IDM

\begin{tabular}{|c|c|}
\hline Questions & $\begin{array}{l}\text { Answers } \\
\%(n=14)\end{array}$ \\
\hline \multicolumn{2}{|c|}{ Compare to using conventional technology, do using IDM there give more profit? } \\
\hline - Decrease & 0.0 \\
\hline - Stable & 42.9 \\
\hline - Increase $10 \%$ & 7.1 \\
\hline - $\quad$ Increase $25 \%$ & 21.4 \\
\hline - $\quad$ Increase $>25 \%$ & 28.6 \\
\hline \multicolumn{2}{|c|}{ Compare to using conventional technology, is the costs production using IDM cheaper? } \\
\hline \multicolumn{2}{|l|}{ - Higher } \\
\hline - Stabile & 42.9 \\
\hline - $\quad$ Decrease $10 \%$ & 35.7 \\
\hline - $\quad$ Decrease $25 \%$ & 7.1 \\
\hline \multirow[t]{2}{*}{ - Decrease $>25 \%$} & 14.3 \\
\hline & 0.0 \\
\hline \multicolumn{2}{|c|}{$\begin{array}{l}\text { Compare to using conventional technology, do using IDM cause pesticide use more efficient? } \\
\quad \text { Increase }\end{array}$} \\
\hline - Stable & 0.0 \\
\hline - $\quad$ Decrease $10 \%$ & 28.6 \\
\hline - $\quad$ Decrease $25 \%$ & 21.4 \\
\hline - $\quad$ Decrease $>25 \%$ & 35.7 \\
\hline \multirow{2}{*}{\multicolumn{2}{|c|}{$\begin{array}{l}\text { Compare to using conventional technology, do using IDM cause fertilizer use more efficient? } \\
\text { Increase }\end{array}$}} \\
\hline & \\
\hline - Stable & 0.0 \\
\hline - $\quad$ Decrease $10 \%$ & 100.0 \\
\hline - $\quad$ Decrease $25 \%$ & 0.0 \\
\hline - $\quad$ Decrease $>25 \%$ & 0.0 \\
\hline
\end{tabular}

Source: Analysis of primary data, 2011 
124 | Joko Mariyono, Integrated Disease Management For Chili Farming

Attachment 3. Knowledge and Farmer Reaction to the Presence of IDM for Chili Opportunity and Possibility to be Try IDM

\begin{tabular}{|c|c|}
\hline Questions & $\begin{array}{l}\text { Answers } \\
\%(n=14)\end{array}$ \\
\hline \multicolumn{2}{|c|}{ Compare to using conventional technology, do using IDM provide more efficient labor? } \\
\hline - Increase & 57.1 \\
\hline - Stabile & 21.4 \\
\hline - $\quad$ Decrease $10 \%$ & 21.4 \\
\hline - $\quad$ Decrease $25 \%$ & 0.0 \\
\hline - Decrease $>25 \%$ & 0.0 \\
\hline \multicolumn{2}{|c|}{ Compare to using conventional technology, is productivity of using IDM higher? } \\
\hline - $\quad$ Decrease & 7.1 \\
\hline - Stabile & 21.4 \\
\hline - Increase $10 \%$ & 28.6 \\
\hline - Increase $25 \%$ & 28.6 \\
\hline - $\quad$ Increase $>25 \%$ & 14.3 \\
\hline \multicolumn{2}{|c|}{$\begin{array}{l}\text { IDM chili technology is very interesting, and it is possible tfor farmer o try in small plot? } \\
\text { - Extremely disagree }\end{array}$} \\
\hline - Disagree & 0.0 \\
\hline - $\quad$ Netral & 7.1 \\
\hline - $\quad$ Agree & 7.1 \\
\hline - Extremely agree & 64.3 \\
\hline \multicolumn{2}{|c|}{$\begin{array}{l}\text { Every new technology e.g IDM has unpredictable and have risk, so the best way is tring first in small plot and find } \\
\text { out more information about that technology? }\end{array}$} \\
\hline - Extremely disagree & 0 \\
\hline - Disagree & 21.4 \\
\hline - $\quad$ Netral & 0 \\
\hline - $\quad$ Agree & 78.6 \\
\hline - $\quad$ Extremely agree & 0 \\
\hline
\end{tabular}

Source: Analysis of primary data, 2011

Attachment 4. Knowledge and farmer reaction to the presence of IDM for chili regarding to impact of IDM

\begin{tabular}{|c|c|}
\hline Questions & $\begin{array}{l}\text { Answers } \\
\%(n=14)\end{array}$ \\
\hline \multicolumn{2}{|c|}{$\begin{array}{l}\text { According to your perception, what is the degree of profitability if using IDM compare to conventional method? } \\
\text { Decrease }\end{array}$} \\
\hline - $\quad$ Stable & 0.0 \\
\hline - Increase $10 \%$ & 7.1 \\
\hline - $\quad$ Increase $25 \%$ & 57.1 \\
\hline - $\quad$ Increase $>25 \%$ & 28.6 \\
\hline \multirow{2}{*}{\multicolumn{2}{|c|}{$\begin{array}{l}\text { According to your perception, what is the degree of suitable use IDM in term of you need? } \\
\quad \text { Very low }\end{array}$}} \\
\hline & \\
\hline - Low & 0.0 \\
\hline - $\quad$ Neutral & 0.0 \\
\hline - High & 42.9 \\
\hline - Very high & 42.9 \\
\hline \multicolumn{2}{|c|}{ According to your perception, what is the degree of difficulties in use of IDM? } \\
\hline - Very low & 42.9 \\
\hline - Low & 35.7 \\
\hline - $\quad$ Neutral & 7.1 \\
\hline - High & 7.1 \\
\hline - Very high & 0.0 \\
\hline \multicolumn{2}{|c|}{$\begin{array}{l}\text { According to your perception, what is the degree in possibilities of use IDM tried by other farmers? } \\
\text { Very low }\end{array}$} \\
\hline - Low & 0.0 \\
\hline - $\quad$ Neutral & 7.1 \\
\hline - High & 14.3 \\
\hline - Very high & 50.0 \\
\hline
\end{tabular}

Source: Analysis of Primary Data, 2011 